\title{
OPTIMASI PENGGUNAAN KARAGENAN DAN KALSIUM SULFAT PADA PEMBUATAN TAHU SUTRA DALAM PENGEMBANGAN PANGAN FUNGSIONAL
}

\author{
Nurheni Sri Palupi ${ }^{1,2 *}$, Nindya Atika Indrastuti ${ }^{1}, \mathrm{Uju}^{3}$, Elvira Syamsir ${ }^{1,2}$ \\ ${ }^{1}$ Departemen Ilmu dan Teknologi Pangan, Fakultas Teknologi Pertanian, IPB University, Bogor \\ ${ }^{2}$ Southeast Asian Food and Agricultural Science and Technology Center LPPM IPB University, Bogor \\ ${ }^{3}$ Departemen Teknologi Hasil Perairan, Fakultas Perikanan dan Ilmu Kelautan, IPB University, Bogor \\ ${ }^{\star}$ Korespondensi: hnpalupi@apps.ipb.ac.id \\ Diterima: 27 Mei 2020/Disetujui: 13 Juli 2020
}

Cara sitasi: Palupi NS, Indrastuti NA, Uju, Syamsir E. 2020. Optimasi penggunaan karagenan dan kalsium sulfat pada pembuatan tahu sutra dalam pengembangan pangan fungsional. Jurnal Pengolahan Hasil Perikanan Indonesia. 23(2): 272-285.

\begin{abstract}
Abstrak
Wedang tahu merupakan olahan tradisional kombinasi antara tahu sutra yang disiram dengan kuah jahe. Kedelai dan jahe yang menjadi bahan baku utama dalam pembuatan wedang tahu memiliki sifat fungsional bagi tubuh bila dikonsumsi. Hal ini menjadikan wedang tahu berpotensi untuk dikembangkan sebagai pangan fungsional. Mutu tekstur tahu sutra menjadi salah satu faktor penentu kualitas wedang tahu. Penambahan karagenan pada pembuatan tahu sutra diharapkan dapat meningkatkan mutu tekstur tahu sutra yang dihasilkan. Tujuan penelitian adalah menentukan kombinasi konsentrasi kalsium sulfat dan karagenan sehingga diperoleh nilai respon rendemen dan tekstur yang optimal menggunakan program Design Expert 7.0. Penentuan formula optimal didasarkan pada hasil pengamatan secara visual (subjektif) yang dikorelasikan dengan hasil pengukuran tekstur secara objektif menggunakan TA-XT2i Texture Analyzer. Formula optimal kemudian dilanjutkan dengan uji sensori, uji proksimat, perhitungan angka kecukupan gizi (AKG), uji tekstur dan uji sineresis. Formula optimal yang direkomendasikan adalah kombinasi kalsium sulfat sebanyak 0,45\% dan karagenan $0,10 \%$ dengan nilai desirability sebesar 0,75 . Formula optimal tersebut memiliki nilai rendemen sebesar 85,36\%, kekerasan sebesar 173,60 gf, daya kohesif sebesar 0,07; elastisitas sebesar 0,54; dan daya kunyah sebesar 6,58 gf.
\end{abstract}

Kata kunci: kalsium sulfat, karagenan, response surface method (RSM), tahu sutra, texture analyze

\section{Optimization the Use of Carrageenan and Calcium Sulfate in Silken Tofu Production in Functional Food Development}

\begin{abstract}
Silken tofu dessert is traditional food consist of silken tofu and ginger soup. Soybean and ginger which are the main raw ingredients of the traditional food have been known for its functional properties when consumed. This makes wedang tahu potentially developed as a functional food. The texture quality of silken tofu is the main factor that determines the quality of wedang tahu. The addition of carrageenan in the wedang tahu processing is expected to improve the quality of silken tofu produced. This study was aimed to determine the combination of calcium sulfate concentration and carrageenan in order to optimize the yields and texture of silken tofu produced by using the Design Expert software version 7.0. The determination of optimum formula was based on visual observation (subjective) which was correlated with the results of texture measurement objectively by using the TA-XT2i Texture Analyzer. The optimum formula was then followed by a sensory test, proximate test, recommended dietary allowance (RDI), texture test, as well as syneresis test. The optimum formula recommended was a combination of $0.45 \%$ calcium sulfate and $0.10 \%$ carrageenan with a desirability value of 0.75 . The yield, hardness, cohesiveness, elasticity and chewing value of its formula were $85.36 \%, 173.60 \mathrm{gf}, 0.07,0.54$, and 6.58 gf respectively.
\end{abstract}

Keywords: calcium sulfate, carrageenan, response surface method (RSM), silken tofu, texture analyzer 


\section{PENDAHULUAN}

Tahu merupakan suatu produk pangan yang berupa padatan lunak dan dibuat melalui proses pengolahan kedelai (Glycine max (L.) Merr.) dengan cara pengendapan proteinnya, dengan atau tanpa penambahan bahan lain yang diizinkan (SNI 1990). Tahu sutra merupakan produk koagulasi sari kedelai utuh tanpa tahapan pengepresan dan pemisahan whey, sehingga curd yang terbentuk memiliki tekstur yang sangat rapuh (Mulin et al. 2001). Salah satu olahan yang memanfaatkan tahu sutra sebagai bahan utama adalah wedang tahu. Wedang tahu merupakan makanan tradisional yang terbuat dari tahu sutra yang disiram menggunakan wedang jahe. Selama ini penjual wedang tahu menjajakan dagangannya dengan cara dipanggul, bukan didorong, hal ini dilakukan karena tekstur tahu sutra yang sangat rapuh sehingga rentan terhadap guncangan jika dijajakan menggunakan gerobak dorong. Di sisi lain, tekstur tahu sutra menjadi salah satu faktor yang menentukan mutu wedang tahu, sehingga perlu dilakukan studi untuk bisa meningkatkan kualitas tekstur tahu sutra agar bisa lebih kokoh selama dijajakan.

Teknologi pengolahan tahu berfokus pada dua hal utama, yaitu rendemen sebagai parameter dari sisi ekonomi dan tekstur sebagai parameter dari sisi penerimaan konsumen (Karim et al. 1999). Shih et al. (1997) menyebutkan bahwa tahu sutra memiliki tekstur seperti keju yang lembut akan tetapi cukup kokoh (tidak hancur) ketika diiris. Jenis dan konsentrasi koagulan yang digunakan akan memengaruhi pembentukan struktur jaringan gel akibat perbedaan kekuatan anion dan kation terhadap kemampuan pengikatan air/water holding capacity (WHC) dalam gel protein kedelai. Jenis koagulan yang umum digunakan dalam pembuatan tahu sutra adalah kalsium sulfat dan glukono delta lakton. Perbedaan kandungan air di dalam curd juga akan memengaruhi kekerasan curd yang dihasilkan (Prabhakaran et al. 2006). Penelitian Shih et al. (1997) melakukan optimasi terhadap proses pengolahan tahu sutra dilihat dari empat faktor, yaitu total padatan susu kedelai, konsentrasi koagulan, suhu pengadukan dan waktu pengadukan dalam skala pilot plan. Penelitian menyatakan bahwa kombinasi total padatan susu kedelai sebesar 11,8-12,3oBrix, kadar koagulan 0,27$0,32 \%$, suhu pengadukan $82-91^{\circ} \mathrm{C}$ dan waktu pengadukan selama 5-11,3 detik memberikan hasil yang optimal terhadap tekstur tahu sutra (Zhang et al. 2013).

Li et al. (2015) melakukan penelitian menggunakan berbagai jenis koagulan, termasuk koagulan dari golongan polisakarida (karagenan, guar gum dan gum arab). Penggunaan karagenan, kalsium asetat, kalsium sulfat dan glukono delta lakton diketahui memberikan pengaruh terhadap rendemen serta sifat fisikokimia dari tahu. Di sisi lain, penggunaan guar gum dan gum arab memberikan pengaruh terhadap kemampuan membentuk gel dari protein kedelai. Penggunaan koagulan campuran 2,93 g $\mathrm{MgCl}_{2}$ dengan 0,2 g karagenan memberikan peluang yang menjanjikan untuk meningkatkan rendemen, tekstur serta sifat sensori tahu. Penambahan karagenan juga dapat menurunkan sineresis pada produk tahu sebesar 1,25\%. Karim et al. (1999) juga menyebutkan bahwa penggunaan karagenan dan kalsium sulfat mampu meningkatkan rendemen dan menurunkan laju sineresis pada tahu reguler yang disimpan pada suhu $4^{\circ} \mathrm{C}$ selama $24 \mathrm{jam}$. Penggunaan polisakarida sebagai koagulan pada pembuatan tahu juga dilakukan oleh Chang et al. (2003) yang menggunakan kitosan sebanyak 2\% untuk meningkatkan kekuatan gel tahu sebesar 5-30\% serta memperpanjang masa simpan produk menjadi 2-10 hari.

Karagenan merupakan polimer polisakarida linier sulfat yang tersusun dengan ikatan $\alpha-1,3$ dan $\beta-1,4$ D-galaktopiranosa (Suptijah et al. 2012). Aplikasi karagenan sudah banyak dilakukan dalam membantu menstabilkan produk (Qotimah et al. 2020; Ibrahim et al. 2020; Siregar et al. 2017; Suptijah et al. 2012). Karagenan mampu berinteraksi dengan makromolekul yang bermuatan, seperti protein sehingga mampu menghasilkan berbagai jenis pengaruh yaitu peningkatan viskositas, pembentukan gel dan pengendapan (Winarno 1996). Keberadaan ion logam polivalen di atas titik isoelektrik protein dapat menjadi jembatan antara gugus 
karboksil pada protein yang bermuatan negatif dengan ester sulfonat dari polisakarida yang juga bermuatan negatif (Glicksman 1983). Sejauh ini belum terdapat penelitian terkait penggunaan koagulan campuran antara karagenan dengan kalsium sulfat dalam pembuatan tahu sutra. Sehubungan dengan itu, penelitian dilaksanakan untuk mendapatkan kombinasi karagenan dan kalsium sulfat yang mampu memperbaiki tekstur dan meningkatkan rendemen produk yang dihasilkan.

\section{BAHAN DAN METODE Bahan dan Alat}

Bahan yang digunakan dalam penelitian ini adalah kacang kedelai varietas US Soybean No 1, rumput laut segar E. cottonii yang berasal dari Nusa Tenggara Timur, kalsium sulfat $\left(\mathrm{CaSO}_{4}\right)$, bahan-bahan kimia kualitas pro analysis (p.a) meliputi $\mathrm{KOH}$ (MerckJerman), isopropil alkohol (Merck-Jerman), $\mathrm{HCl}$ (Merck-Jerman), $\mathrm{NaOH}$ (MerckJerman), $\mathrm{BaCl}_{2}$ (Showa-Jepang), $\mathrm{H}_{2} \mathrm{O}_{2}$ (MerckJerman), $\mathrm{KCl}$ (Merck-Jerman), $\mathrm{K}_{2} \mathrm{SO}_{4}$ (MerckJerman), $\mathrm{HgO}$ (Merck-Jerman), $\mathrm{H}_{2} \mathrm{SO}_{4}$ (MerckJerman), hexana (Merck-Jerman), indikator phenolftalein (Merck-Jerman), $\mathrm{H}_{3} \mathrm{BO}_{3}$ (CICAJepang), $\mathrm{Na}_{2} \mathrm{~S}_{2} \mathrm{O}_{3}$ (Merck-Jerman). Alat-alat yang digunakan dalam penelitian ini adalah shaker water bath (Accuma-India), TA-XT2i Texture Analyzer (Stable Micro SystemInggris), brookfield viscometer (BrookfieldAS), reflux (Labconco-Kansas), oven (WTB Binder-Jerman), dan tanur (Thermolyne-AS).

\section{Metode Penelitian \\ Ekstraksi dan karakterisasi fisiko- kimia karagenan}

Tahapan ekstraksi karagenan didasarkan pada metode Hayashi et al. (2007a) dengan sedikit modifikasi. Rumput laut segar terlebih dahulu dikeringkan selama 24 jam pada oven pengering dengan suhu $60^{\circ} \mathrm{C}$. Rumput laut kering sebanyak $30 \mathrm{~g}$ direndam dalam 400 $\mathrm{ml} \mathrm{KOH} \mathrm{6 \%} \mathrm{(w/v)} \mathrm{selama} \pm 17$ jam. Ekstraksi dilakukan pada suhu $80^{\circ} \mathrm{C}$ selama 2 jam pada $400 \mathrm{~mL} \mathrm{KOH} \mathrm{6 \%} \mathrm{(w/v).} \mathrm{Tahap} \mathrm{selanjutnya}$ adalah pencucian menggunakan air mengalir sampai bersih dan dilanjutkan pemanasan pada suhu $80^{\circ} \mathrm{C}$ selama 2 jam dalam $700 \mathrm{~mL}$ akuades sampai menjadi bubur. Bubur rumput laut kemudian diencerkan menggunakan air hangat dengan volume 4 kali volume bubur. Filtrat diendapkan menggunakan IPA dengan perbandingan 1:1 (v/v). Serat karagenan yang diperoleh dikeringkan menggunakan oven pada suhu $60^{\circ} \mathrm{C}$ sampai berat konstan $( \pm 36$ jam) untuk kemudian dihaluskan. Analisis kadar sulfat (FMC Corp. 1977), kadar abu tidak larut asam (FMC Corp. 1977), kekuatan gel (Hayashi et al. 2007b), viskositas (Munoz 2004 termodifikasi) dan rendemen (FMC Corp. 1977) dilakukan terhadap tepung karagenan hasil ekstraksi.

\section{Pembuatan tahu sutra}

Pembuatan tahu sutra didasarkan pada metode Yuan dan Meng (2011) dengan sedikit modifikasi. Modifikasi yang dilakukan yaitu penambahan jumlah air penggilingan menjadi lima kali berat kedelai kering, dilakukan penambahan karagenan sebelum susu kedelai dipanaskan dan tidak adanya proses pengepresan curd.

Kacang kedelai bersih direndam menggunakan air bersih dengan perbandingan air:kedelai sebesar 3:1 pada suhu ruang selama 9 jam. Kedelai kemudian dikupas, dibersihkan dan digiling menggunakan blender hingga menjadi bubur kedelai (slurry). Proses penggilingan menggunakan air bersih dengan perbandingan air:kedelai sebesar 5:1.

Slurry kemudian disaring ampasnya (okara) menggunakan kain blacu berwarna putih. Sejumlah karagenan ditambahkan ke dalam sari kedelai untuk kemudian dipanaskan sampai suhu $90^{\circ} \mathrm{C}$ selama 5 menit di atas penangas air sambil diaduk. Proses koagulasi dilakukan dengan menurunkan suhu sari kedelai sampai $75^{\circ} \mathrm{C}$, kemudian ditambahkan $\mathrm{CaSO}_{4}$. Curd didinginkan dan disimpan pada suhu refrigerator selama satu malam. Pengujian rendemen mengacu kepada Prabhakaran et al. 2006 sedangkan tekstur menurut Obatolu 2007.

\section{Rancangan dan optimasi formula tahu sutra}

Penelitian ini menggunakan metode Response Surface Methodology (RSM) dengan rancangan D-optimal untuk mendapatkan 
konsentrasi dari variabel-variabel yang digunakan sehingga dihasilkan respon yang optimal (Padil et al. 2011). Konsentrasi kalsium sulfat $(0,2-0,5 \%)$ dan karagenan $(0,1-$ $0,2 \%)$ dipilih sebagai variabel. Penentuan batas minimum dan maksimum dari masingmasing variabel didasarkan pada penelitian yang telah dilaksanakan sebelumnya (Kao et al. 2003; Karim et al. 1999) dan juga didasarkan pada pengamatan secara subjektif terhadap tekstur tahu sutra yang dihasilkan. Respons yang digunakan dalam penelitian ini adalah rendemen dan tekstur (meliputi kekerasan, daya kohesif, elastisitas, dan daya kunyah). Penentuan respons didasarkan pada Karim et al. (1999) yang menyebutkan bahwa teknologi pembuatan tahu berfokus pada dua hal utama yaitu rendemen yang memberikan pengaruh dari sisi ekonomi dan tekstur yang memberikan pengaruh dari sisi penerimaan konsumen. Pengukuran respons rendemen tahu sutra didasarkan pada metode Prabhakaran et al. (2006), sedangkan pengukuran tekstur didasarkan pada metode Obatolu (2007).

Formula optimal ditentukan berdasarkan hasil analisis respons rendemen dan tekstur (meliputi kekerasan, daya kohesif, elastisitas, dan daya kunyah) terhadap 16 kombinasi formula yang direkomendasikan oleh RSM. Optimasi dilakukan untuk memperoleh formula optimal dengan nilai prediksi variabel respons yang paling sesuai dengan nilai variabel respons yang diinginkan. Kesesuaian antara nilai variabel respons yang diprediksi dengan nilai variabel respons yang diinginkan digambarkan dengan nilai desirability. Formula optimal yang direkomendasikan merupakan formula dengan nilai desirability tertinggi (Tegar 2010).

\section{Karakterisasi kimia dan fisik tahu sutra formula optimal}

Karakterisasi kimia tahu sutra formula optimal dilakukan dengan analisis kadar air metode vakum (AOAC 2012), analisis kadar abu dengan metode pengabuan kering (AOAC 2012), analisis kadar lemak metode soxhlet (AOAC 2012), analisis kadar protein metode kjeldahl (AOAC 2012) dan penentuan kadar karbohidrat yang dilakukan berdasarkan perhitungan by difference. Karakterisasi fisik tahu sutra formula optimal meliputi uji tekstur menggunakan TA-XT2i Texture Analyzer (Obatolu 2007) dan uji sineresis (AOAC 1995).

\section{Karakterisasi sensori tahu sutra formula optimal}

Karakterisasi sensori dilakukan untuk mengetahui tingkat kesukaan panelis terhadap tahu sutra formula optimal dibandingkan terhadap tahu sutra komersial. Tahu sutra komersialdiperolehdaripedagangwedangtahu di wilayah Suryakencana, Bogor. Uji sensori dilakukan oleh 70 orang panelis umum yang diminta untuk melakukan analisis terhadap warna, aroma, rasa, tekstur dan keseluruhan (BSN 2006). Sampel disajikan satu per satu untuk menghindari bias. Penilaian dilakukan menggunakan skala hedonik dengan rentang 1 sampai dengan 7. Skala 1 menunjukkan sangat tidak suka dan skala 7 menunjukkan sangat suka. Hasil analisis kedua produk kemudian dibandingkan dan diolah dengan uji independent T-test menggunakan SPSS 20.0 .

\section{HASIL DAN PEMBAHASAN Ekstraksi dan Karakteristik Sifat Fisiko-Kimia Karagenan}

Secara umum karagenan refined yang dihasilkan sudah memenuhi standar FAO (Table 1). Rendemen yang dihasilkan pada penelitian ini bernilai $42,14 \%$. Nilai rendemen tersebut telah memenuhi standar persyaratan minimum rendemen karagenan yang ditetapkan oleh BSN (2009) yaitu tidak kurang dari 25\%. Viskositas merupakan daya aliran molekul dalam sistem larutan (Glicksman 1983). Nilai viskositas yang dihasilkan dari penelitian ini adalah 19,67 cps. Hasil viskositas dari penelitian ini telah memenuhi standar minimum viskositas karagenan yang ditetapkan oleh FAO (2007) yaitu sebesar 5 cps yang diukur pada konsentrasi 1,5\% dengan suhu $75^{\circ} \mathrm{C}$ menggunakan viscometer brookfield.

Kekuatan gel menunjukkan kemampuan karagenan dalam pembentukan gel (Campo et al. 2009). Hasil dari analisis kekuatan gel adalah $454,48 \mathrm{~g} / \mathrm{cm}^{2}$. Nilai tersebut masih lebih tinggi jika dibandingkan 
Table 1 Comparison of carrageenan characteristics with the FAO standard

\begin{tabular}{lcr}
\hline \multicolumn{1}{c}{ Characteristics } & Carrageenan & FAO Standard $^{\mathrm{a}}$ \\
\hline Yield (\%) & $42.14 \pm 10.68$ & Min. 25 \\
Viscosity (cps) & $19.67 \pm 1.36$ & Min. 5 \\
Gel strength $\left(\mathrm{g} / \mathrm{cm}^{2}\right)$ & $454.48 \pm 26.79$ & $20-500$ \\
Acid insoluble ash (\%) & $0.85 \pm 0.00$ & 1 \\
Sulfat (\%) & $11.44 \pm 0.29$ & $15-40$ \\
\hline
\end{tabular}

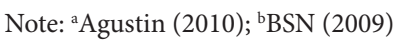

dengan hasil penelitian Distantina (2013) yang melaporkan bahwa kekuatan gel kappa karagenan sebesar 208,96 g/ $/ \mathrm{cm}^{2}$. Kekuatan gel karagenan yang dihasilkan pada penelitian ini telah memenuhi standar yang ditetapkan oleh FAO (2007), yaitu $20-500 \mathrm{~g} / \mathrm{cm}^{2}$.

Kadar abu tak larut asam merupakan garam-garam klorida yang tidak larut asam yang sebagian besar adalah garam logam berat dan silika yang ditemukan di alam sebagai kuarsa, pasir, dan batu (Diharmi et al. 2011). Kadar abu tak larut asam merupakan salah satu kriteria dalam menentukan tingkat kebersihan dalam pengolahan karagenan (Basmal et al. 2003). Kadar abu tak larut asam yang dihasilkan adalah $0,85 \%$. Nilai tersebut masih memenuhi kisaran standar mutu karagenan yang ditetapkan oleh FAO (2007) yaitu kadar abu tak larut asam maksimal $1 \%$.

Kadar sulfat merupakan parameter yang digunakan untuk berbagai jenis produk yang terdapat di dalam alga merah (Winarno et al. 1996). Banyaknya fraksi sulfat dan kesetimbangan kation dalam air menentukan kekentalan dan kekuatan gel yang dibentuk oleh karagenan (Campo et al. 2009). Kadar sulfat yang dihasilkan pada penelitian ini adalah 11,44\%. Kadar sulfat hasil penelitian ini belum memenuhi kisaran standar mutu karagenan yang ditetapkan FAO (2007) yaitu sebesar $15-40 \%$. Kadar sulfat karagenan berbading lurus dengan nilai viskositas dan berbanding terbalik dengan kekuatan gel karagenan (Gliksman 1982). Semakin kecil kadar sulfat karagenan maka sifat gelasinya akan meningkat (Campo et al. 2009).

\section{Respons Optimasi Formula Tahu Sutra}

Penelitian ini menggunakan jenis dan konsentrasi koagulan sebagai faktor sedangkan variabel lainnya dikondisikan sama. Dua faktor tersebut masingmasing ditetapkan nilai maksimal dan nilai minimalnya berdasarkan penelitian yang telah dilakukan sebelumnya dan berdasarkan hasil trial error yang dilakukan di laboratorium. Nilai yang digunakan untuk konsentrasi kalsium sulfat (\%) berkisar antara 0,2 sampai 0,5 (Kao et al. 2003). Konsentrasi karagenan (\%) berkisar antara 0,1 sampai 0,2 (Karim et al. 1999). Berdasarkan teknik RSM dengan rancangan D-optimal, kombinasi konsentrasi kalsium sulfat dan konsentrasi karagenan dengan hasil pengukuran 16 unit percobaan terhadap kelima respons, yaitu rendemen dan tekstur (kekerasan, daya kohesif, elastisitas, dan daya kunyah). Penetapan target (sasaran) didasarkan pada hasil pengamatan secara visual (subjektif) yang dikorelasikan dengan hasil pengukuran tekstur secara objektif menggunakan TA-XT2i Texture Analyzer. Rendemen menggambarkan tingkat efisiensi pembuatan tahu sutra. Semakin tinggi nilai rendemen maka proses pembuatan tahu sutra semakin efisien.

\section{Formula Tahu Sutra Optimal Berdasarkan Respons Rendemen dan Tekstur}

Karim et al. (1999) menyatakan bahwa teknologi pembuatan tahu berfokus pada dua hal utama yaitu rendemen yang memberikan pengaruh dari sisi ekonomi dan tekstur yang memberikan pengaruh dari sisi penerimaan konsumen. Menurut Poysa dan Woodrow (2002), tahu yang baik adalah yang memiliki tekstur lembut, kompak, koheren, tidak elastis dan tidak kaku. Pada penelitian ini, mutu tahu sutra dianggap baik apabila memiliki tekstur yang lembut namun kompak. Table 2 merupakan kriteria penentuan formula optimal tahu sutra. 
Table 2 Criteria for determining the optimum formula

\begin{tabular}{llrrr}
\hline \multicolumn{1}{c}{ Variable } & \multicolumn{1}{c}{ Goal } & Minimum & Maximum & Importance \\
\hline CaSO $_{4}(\%)$ & In range & 0.20 & 0.50 & $3(+++)$ \\
Carrageenan (\%) & In range & 0.10 & 0.20 & $3(+++)$ \\
Yield (\%) & Maximize & 76.17 & 88.04 & $5(+++++)$ \\
Hardness (gf) & In range & 90.00 & 180.00 & $3(+++)$ \\
Cohesiveness & Maximize & 0.03 & 0.09 & $5(+++++)$ \\
Elasticity & In range & 0.35 & 0.55 & $3(+++)$ \\
Chewiness (gf) & In range & 2.00 & 8.50 & $3(+++)$ \\
\hline
\end{tabular}

Terdapat lima solusi formula optimal yang disarankan dengan nilai desirability yang tidak jauh berbeda sehingga memberikan prediksi nilai respons yang hampir sama. Formula yang dipilih sebagai formula optimal adalah $0,45 \%$ kalsium sulfat dengan 0,10\% karagenan, selain karena memiliki desirability tertinggi, juga karena memiliki proporsi karagenan yang paling kecil dibandingkan empat solusi formula lainnya. Hal ini dilakukan mengingat harga karagenan yang sedikit mahal sehingga dipilih formula dengan proporsi karagenan terkecil untuk meminimalkan biaya.

Setelah diperoleh kombinasi koagulan optimal, maka dilakukan pengujian terhadap respons tesktur dari formula tahu sutra terpilih. Berdasarkan hasil pengukuran aktual, diperoleh bahwa formula terpilih memiliki rendemen $85,36 \%$, kekerasan 173,60 gf, daya kohesif 0,07 ; elastisitas 0,54 ; dan daya kunyah 6,58 gf. Menurut prediksi program RSM, tahu sutra formula optimal memiliki nilai rendemen sebesar 87,32\%, kekerasan 171,54 gf, daya kohesif 0,07 ; elastisitas 0,54 ; dan daya kunyah 6,58 gf. Hasil pengukuran rendemen dan tekstur terhadap tahu sutra terpilih secara aktual masih berada dalam selang 95\% PI low dan 95\% PI high. Nilai 95\% PI (prediction interval) menunjukkan nilai terendah dan tertinggi dari kisaran yang diprediksi, di mana memiliki kepercayaan dari pengamatan individual sebesar 95\%. Berdasarkan hasil pengujian tersebut, maka dapat disimpulkan bahwa hasil optimasi penggunaan kalsium sulfat dan karagenan pada pembuatan tahu sutra terverifikasi.

\section{Optimasi Rendemen Tahu Sutra}

Model prediksi untuk respon rendemen adalah cubic. Persamaan matematik untuk respon rendemen adalah sebagai berikut:

Rendemen $=9,60+533,33 \mathrm{~A}+116,71 \mathrm{~B}-2890,19 \mathrm{AB}-$

$$
\begin{aligned}
& -675,65 A^{2}+2344,70 B^{2}+3051,35 \\
& A^{2} B+2092,98 A B^{2}+46,50 A^{3}-6116,24 \\
& B^{3}
\end{aligned}
$$

Keterangan:

$\mathrm{A}=$ konsentrasi $\mathrm{CaSO}_{4}$

$\mathrm{B}=$ konsentrasi karagenan

Respons rendemen secara visual dapat dilihat pada Figure 1. Rendemen tahu sutra mengalami peningkatan seiring dengan meningkatnya konsentrasi $\mathrm{CaSO}_{4}$ dari $0,20-$ $0,40 \%$. Hal ini sesuai dengan penelitian Kao et al. (2003) yang menyebutkan bahwa seiring meningkatnya konsentrasi $\mathrm{CaSO}_{4}$ dari 0,20-0,40\% akan meningkatkan rendemen tahu secara signifikan dan pada konsentrasi yang lebih tinggi yaitu $0,50 \%$ rendemen tahu mengalami penurunan. Konsentrasi $\mathrm{CaSO}_{4}$ yang terlalu rendah tidak mencukupi untuk membentuk curd tahu yang kompak. Pada konsentrasi yang terlalu tinggi cross-linked yang terbentuk semakin banyak sehingga banyak air yang keluar dari jaringan internal menghasilkan tahu yang terlalu kompak dan bersifat poros. Semakin banyak crosslinked yang terbentuk maka sineresis akan meningkat dan sebagian whey akan terbuang akibatnya matriks protein menjadi lebih padat dan kompak (Sunet et al.1991).

Peningkatan konsentrasi karagenan juga memberikan korelasi yang positif terhadap peningkatan rendemen tahu sutra. Di atas titik isoelektrik, keberadaan ion polivalen seperti $\mathrm{Ca}^{2+}$ dapat membentuk jembatan antara muatan negatif gugus karboksil protein 


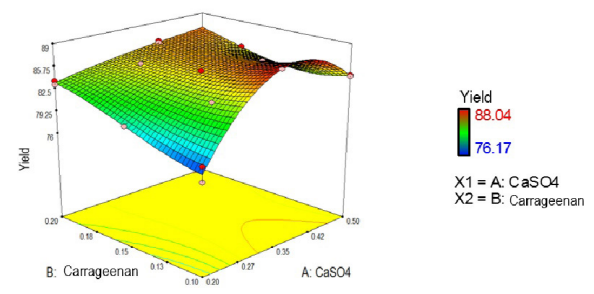

Figure 1 Yield recovery of silken tofu response based on the concentration of calcium sulfate (A) and carrageenan (B)

dengan gugus ester sulfat karagenan. Struktur jaringan yang dibentuk oleh karagenan mampu mengikat air lebih banyak ke dalam jaringan gel, mengurangi sineresis dan meningkatkan rendemen (Karim et al. 1999).

\section{Optimasi Kekerasan Tahu Sutra}

Model prediksi untuk respon rendemen adalah cubic. Persamaan matematik untuk respon rendemen adalah sebagai berikut:

Kekerasan $=-54,26+1290,85$ A-1694,89 B-3114,64

$\mathrm{AB}-1407,37 \mathrm{~A}^{2}+14916,16 \mathrm{~B}^{2}+15273,01$

$\mathrm{A}^{2} \mathrm{~B}-28338,18 \mathrm{AB}^{2}-874,87 \mathrm{~A}^{3}$

$$
-10565,48 \mathrm{~B}^{3}
$$

Keterangan:

$\mathrm{A}=$ konsentrasi $\mathrm{CaSO}_{4}$

$\mathrm{B}=$ konsentrasi karagenan

Respons kekerasan secara visual dapat dilihat pada Figure 2. Kekerasan tahu sutra mengalami peningkatan seiring dengan bertambahnya konsentrasi kalsium sulfat. Kekerasan merupakan struktur padat dan kompak dari tahu sebagai akibat dari kemampuan kalsium sulfat untuk menciptakan struktur yang lebih padat dengan membuat molekul protein saling berdekatan. Kao et al. (2003) menyatakan bahwa semakin bertambahnya konsentrasi kalsium sulfat maka jembatan antara ion $\mathrm{Ca}^{2+}$ dengan protein akan semakin banyak sehingga struktur yang dihasilkan lebih padat dan lebih kompak.

Peningkatan konsentrasi karagenan memberikan kecenderungan terhadap peningkatan nilai kekerasan tahu sutra. Peningkatan nilai kekerasan ini diduga disebabkan adanya interaksi antara karagenan dengan protein yang menghasilkan peningkatan gel strength ( $\mathrm{Li}$ et al. 2015). Peningkatan kekerasan juga disebabkan karena karagenan merupakan hidrokoloid pembentuk gel. Pembentukan gel merupakan fenomena terbentuknya ikatan (cross-linked) antar rantai polimer membentuk struktur jaringan tiga dimensi yang akan memerangkap air sehingga terbentuklah struktur gel yang kaku (Saha et al. 2010).
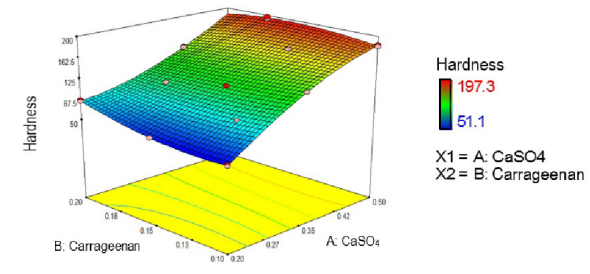

Figure 2 The hardness response of silken tofu response based on the concentration of calcium sulfate (A) and carrageenan (B) 


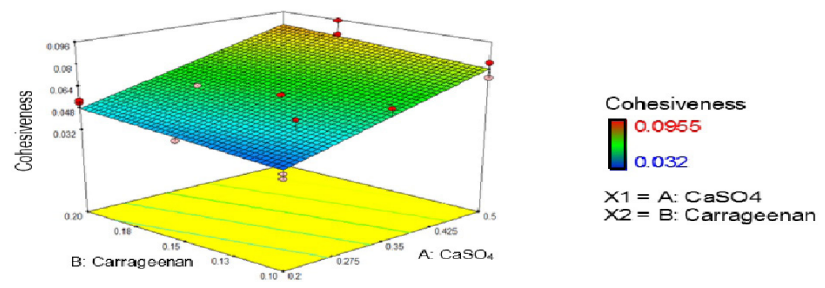

Figure 3 The cohesiveness response of silken tofu response based on the concentration of calcium sulfate (A) and carrageenan (B)

\section{Optimasi Daya Kohesif Tahu Sutra}

Model prediksi untuk respon rendemen adalah linear. Persamaan matematik untuk respons rendemen adalah sebagai berikut:

Daya kohesif $=0,03+0,13 \mathrm{~A}+0,09 \mathrm{~B}$

Keterangan:

$\mathrm{A}=$ konsentrasi $\mathrm{CaSO}_{4}$

$\mathrm{B}=$ konsentrasi karagenan

Respons daya kohesif secara visual dapat dilihat pada Figure 3. Konsentrasi kalsium sulfat dan karagenan yang tinggi, cross-linked antar rantai polimer protein-Ca-karagenan yang terbentuk semakin banyak sehingga menghasilkan tahu yang padat dan kompak (Saha et al. 2010). Hal ini juga sesuai dengan penelitian Li et al. (2015) yang menyatakan bahwa peningkatan jumlah karagenan akan meningkatkan daya kohesif produk tahu. Kao et al. (2003) juga menyatakan bahwa daya kohesif tahu meningkat secara signifikan seiring dengan meningkatnya konsentrasi kalsium sulfat dari $0,20-0,40 \%$. Peningkatan daya kohesif ini disebabkan karena pada konsentrasi kalsium sulfat yang tinggi, tahu mampu membentuk mikrostruktur yang kontinu dan seragam sehingga jaringan internal yang terbentuk semakin kompak. Konsentrasi kalsium sulfat yang rendah akan menghasilkan produk tahu dengan mikrostruktur yang kasar dengan banyak fragmen serta pori-pori yang besar.

\section{Optimasi Elastisitas Tahu Sutra}

Model prediksi untuk respon rendemen adalah linear. Persamaan matematik untuk respons rendemen adalah sebagai berikut:

Elastisitas $=-0,019+1,09 \mathrm{~A}+0,63 \mathrm{~B}$

Keterangan:

$\mathrm{A}=$ konsentrasi $\mathrm{CaSO}_{4}$

$\mathrm{B}=$ konsentrasi karagenan

Respons elastisitas secara visual dapat dilihat pada Figure 4. Elastisitas tahu sutra meningkat seiring dengan meningkatnya konsentrasi kalsium sulfat. Hal ini sesuai dengan penelitian Kao et al. (2003) yang menyebutkan bahwa semakin tinggi konsentrasi kalsium sulfat yang digunakan pada pembuatan tahu maka

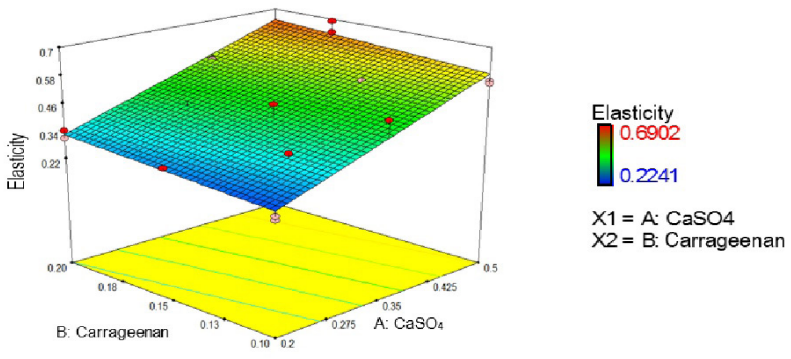

Figure 4 The elasticity response of silken tofu response based on the concentration of calcium sulfate (A) and carrageenan (B) 


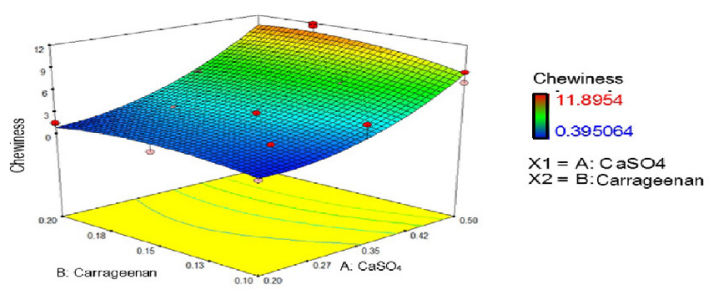

Figure 5 The chewiness response of silken tofu response based on the concentration of calcium sulfate (A) and carrageenan (B)

akan meningkatkan nilai elastisitas produk tahu. Elastisitas tahu sutra juga mengalami peningkatan seiring dengan meningkatnya konsentrasi karagenan. Ikatan kovalen antara karagenan dengan protein akan bergabung membentuk struktur gel yang akan memberikan kontribusi terhadap elastisitas tahu sutra (Nishinari et al. 2014).

\section{Optimasi Daya Kunyah Tahu Sutra}

Model prediksi untuk respons rendemen adalah quadratic. Persamaan matematik untuk respons rendemen adalah sebagai berikut:

Daya kunyah $=-1,3729-47,61 \mathrm{~A}+101,85 \mathrm{~B}+72,16$

$$
\mathrm{AB}+93,78 \mathrm{~A}^{2}-381,19 \mathrm{~B}^{2}
$$

Keterangan:

$\mathrm{A}=$ konsentrasi $\mathrm{CaSO}_{4}$

$\mathrm{B}=$ konsentrasi karagenan

Respons daya kunyah secara visual dapat dilihat pada Figure 5. Peningkatan konsentrasi kalsium sulfat dan konsentrasi karagenan akan meningkatkan daya kunyah tahu sutra. Berdasarkan Kao et al. (2003) peningkatan konsentrasi kalsium sulfat akan membentuk struktur tahu yang kompak dan rapat. Struktur yang rapat dan kompak akan memberikan korelasi yang positif terhadap nilai kekerasan dan elastisitas tahu sutra. Daya kunyah merupakan hasil kali antara kekerasan, daya kohesif dan elastisitas. Sehingga semakin tinggi nilai kekerasan dan elastisitas produk, maka semakin tinggi daya kunyahnya. Peningkatan konsentrasi karaginan juga meningkatkan daya kunyah tahu sutra. Hal ini sesuai dengan penelitian Li et al. (2015) yang menyebutkan bahwa peningkatan konsentrasi karagenan akan meningkatkan daya kunyah tahu. Interaksi antara karagenan-protein akan meningkatkan kekerasan tahu sutra. Semakin tinggi tingkat kekerasan suatu produk maka dibutuhkan energi yang lebih tinggi untuk mengunyah bahan pangan tersebut hingga siap untuk ditelan.

\section{Karakteristik Penerimaan Tahu Sutra Terpilih}

Table 3 merupakan karakteristik sensori tahu sutra formula komersial dan tahu sutra terpilih. Tahu sutra formula komersial yang dimaksud adalah tahu sutra yang tahapan pembuatannya menggunakan pendekatan pembuatan tahu sutra yang ada di pasaran dan hanya menggunakan kalsium sulfat saja sebagai koagulan.

Hasil uji Independent-Sample $T$ Test menunjukkan bahwa panelis lebih menyukai warna tahu sutra komersial dibandingkan

Table 3 Sensory characteristics of commercial silken tofu and selected formula

\begin{tabular}{lccccc}
\hline \multirow{2}{*}{ Formula } & \multicolumn{5}{c}{ Rating Scale* } \\
\cline { 2 - 6 } & Color & Odor & Taste & Texture & Overall \\
\hline Commercial silken tofu & $5.69 \pm 0.84^{\mathrm{a}}$ & $4.43 \pm 1.52^{\mathrm{a}}$ & $3.74 \pm 1.46^{\mathrm{a}}$ & $4.89 \pm 1.34^{\mathrm{a}}$ & $4.44 \pm 1.16^{\mathrm{a}}$ \\
Selected formula & $5.11 \pm 1.08^{\mathrm{b}}$ & $4.90 \pm 1.23^{\mathrm{b}}$ & $4.73 \pm 1.35^{\mathrm{b}}$ & $5.31 \pm 1.19^{\mathrm{b}}$ & $5.17 \pm 0.88^{\mathrm{b}}$ \\
\hline
\end{tabular}

Note: ${ }^{\star}$ Hedonic scale ranges from 1 (very dislike) to 7 (very like); a-b numbers in the same column which are followed by different letters, significantly different $(p<0.05)$ 
Table 4 Comparison the nutrition value of selected formula with the quality standard of tofu according to DKBM and instant silken tofu

\begin{tabular}{lrrr}
\hline \multicolumn{1}{c}{ Characteristics } & Selected Formula & DKBM $^{\mathrm{a}}$ & Instant silken tofu $^{\mathrm{b}}$ \\
\hline Water content (\%wb) & $92.38 \pm 0.03$ & 82.20 & 65.79 \\
Ash (\%db) & $4.20 \pm 0.00$ & 7.86 & 4.08 \\
Protein (\%db) & $41.59 \pm 0.22$ & 61.24 & 20.96 \\
Lipid (\%db) & $52.04 \pm 0.35$ & 26.40 & 1.17 \\
Carbohydrate (\%db) & $2.17 \pm 0.13$ & 4.49 & 71.14 \\
\hline
\end{tabular}

Note: aDepkes RI (1995) 'beptiana (2011)

dengan warna tahu sutra formula optimal secara signifikan $(p<0,05)$. Karagenan yang digunakan dalam penelitian ini memilikiwarna kuning kecokelatan, sehingga memberikan pengaruh terhadap warna tahu sutra yang dihasilkan. Hal inilah yang menyebabkan tahu sutra formula optimal memiliki warna yang lebih kuning dibandingkan dengan tahu sutra komersial. Hasil uji Independent-Sample T Test menunjukkan penerimaan aroma, rasa, dan tekstur tahu sutra formula optimal berbeda nyata $(p<0,05)$ dengan tahu sutra komersial.

\section{Karakteristik Kimia dan Perhitungan Nilai Gizi Tahu Sutra Terpilih}

Karakteristik kimia tahu sutra formula terpilih dibandingkan dengan DKBM (Daftar Komposisi Bahan Makanan) tahun 1995 dan tahu sutra instan hasil penelitian Septiana (2011). Kadar air tahu sutra terpilih lebih tinggi jika dibandingkan dengan standar tahu menurut DKBM (1995). Hal ini disebabkan karena tahu sutra tidak mengalami proses pengepresan sehingga kandungan air yang terperangkap di dalam curd sangat tinggi. Kadar air formula terpilih juga lebih tinggi jika dibandingkan dengan tahu sutra instan hasil penelitian Septiana (2011). Hal ini disebabkan karena tahu sutra instan sudah mengalami proses pengeringan spray dryer sehingga kadar airnya berkurang secara signifikan.

Kadar abu tahu sutra formula terpilih lebih rendah jika dibandingkan dengan standar produk tahu menurut DKBM dan hampir setara dengan kadar abu tahu sutra instan. Kadar protein tahu sutra formula terpilih lebih rendah jika dibandingkan dengan DKBM akan tetapi masih lebih tinggi jika dibandingkan dengan tahu sutra instan. Perbedaan ini dapat disebabkan karena adanya perbedaan penggunaan jenis dan konsentrasi koagulan, pengadukan selama koagulasi, dan tekanan terhadap curd akan memberikan variasi kadar air dan kadar protein tahu (Blazek 2008). Kadar lemak tahu sutra terpilih lebih tinggi dibandingkan dengan DKBM dan tahu sutra instan. Kedelai yang memiliki kadar lemak tinggi umumnya akan menghasilkan tahu dengan kadar lemak tinggi. Perbedaan jenis koagulan yang digunakan tidak memberikan pengaruh yang signifikan terhadap kandungan lemak tahu (Permana 2001). Hasil uji karbohidrat produk tahu sutra terpilih lebih rendah dibandingkan dengan standar mutu tahu berdasarkan DKBM dan tahu sutra instan. Tahu sutra instan dalam penelitian Septiana (2011) menggunakan koagulan jenis glukono delta lakton (GDL). GDL merupakan karbohidrat yang berisi gugus lakton yang dihidrolisis secara bertahap membentuk asam glukonat (Chen et al. 2016). Hal ini menyebabkan tingginya kadar karbohidrat pada tahu sutra instan. Table 4 merupakan perbandingan nilai gizi tahu sutra formula optimal dan standar mutu tahu menurut DKBM.

Nilai AKG digunakan sebagai pedoman bagi industri pangan untuk membuat label pangan dan kandungan zat gizi dalam produk (Sanusi 2006). Pada penelitian ini, perhitungan nilai gizi tahu sutra formula terpilih dibandingkan terhadap tahu reguler dan tahu sutra komersial berdasarkan basis kering. Perhitungan energi per sajian serta \%AKG pada tahu reguler dan tahu sutra didasarkan pada informasi nilai gizi yang 
Table 5 Nutrition value of selected formula and commercial tofu

\begin{tabular}{|c|c|c|c|c|}
\hline Characteristics & Type & Protein & Lipid & Carbohydrate \\
\hline \multirow{3}{*}{$\begin{array}{l}\text { Content } \\
(\mathrm{g} / 100 \mathrm{~g}))\end{array}$} & Selected formula & 41.59 & 52.04 & 2.17 \\
\hline & Commercial silken tofu ${ }^{* *}$ & 21.05 & 10.53 & 5.26 \\
\hline & Commercial reguler tofu $\mathrm{u}^{* * *}$ & 51.71 & 36.19 & 12.10 \\
\hline \multirow{3}{*}{$\begin{array}{l}\text { Calory per } \\
\text { serving size } \\
\text { (kkal/100g) }\end{array}$} & Selected formula & 166.35 & 468.39 & 8.66 \\
\hline & Commercial silken tofu ${ }^{\star *}$ & 84.21 & 94.74 & 21.05 \\
\hline & Commercial reguler tofu ${ }^{* * *}$ & 206.83 & 325.75 & 48.40 \\
\hline \multirow{3}{*}{$\begin{array}{l}\text { Recommended } \\
\text { Dietary } \\
\text { Allowance }(\%)^{*}\end{array}$} & Selected formula & 83.18 & 94.62 & 0.67 \\
\hline & Commercial silken tofu ${ }^{\star *}$ & 42.11 & 19.14 & 1.62 \\
\hline & Commercial reguler tofu ${ }^{* * *}$ & 103.41 & 65.81 & 3.72 \\
\hline
\end{tabular}

Note: ${ }^{\star} \%$ RDA based on energy need $2000 \mathrm{kkal} ;{ }^{* *}$ Commercial silken tofu brand $\mathrm{A} ;{ }^{* *}$ Commercial reguler tofu brand B

tercantum di label kemasan. Berdasarkan informasi yang tertera pada label, komposisi tahu reguler A adalah kedelai, air, garam dan kunyit. Tahu jenis ini menggunakan whey protein hasil pembuatan tahu sebelumnya sebagai koagulan. Berdasarkan informasi yang tertera pada label, komposisi tahu sutra B adalah kedelai organik dan air. Jenis koagulan yang digunakan dalam pembuatan tahu ini adalah kombinasi antara kalsium sulfat $\left(\mathrm{CaSO}_{4}\right)$ dan nigari $\left(\mathrm{MgCl}_{2}\right)$. Informasi nilai gizi tahu sutra terpilih, tahu reguler dan tahu sutra dapat dilihat pada Table 5.

Tahu reguler memiliki nilai protein yang paling tinggi dibandingkan tahu sutra terpilih dan tahu sutra. Perbedaan kadar protein ini disebabkan oleh perbedaan varietas kedelai, jumlah air pengekstrak, jenis koagulan dan aplikasi pengepresan. Kedelai yang memiliki kandungan protein yang lebih tinggi umumnya akan menghasilkan tahu dengan kadar protein yang lebih tinggi (Schaefer dan Love 1992). Yuwono dan Susanto (2006) menyebutkan bahwa peningkatan jumlah air yang digunakan pada tahap ekstraksi akan menyebabkan adanya peningkatan protein kedelai yang terekstrak dan larut bersama air. Perbedaan jenis koagulan menyebabkan perbedaan laju koagulasi tahu. Proses koagulasi yang terlalu cepat atau terlalu lambat menyebabkan protein yang terkoagulasi tidak sempurna (Fahmi 2010). Murdia dan Wadhwani (2010) menyebutkan bahwa semakin tinggi tekanan yang diaplikasikan selama proses pengepresan, maka akan meningkatkan kandungan protein tahu secara signifikan. Hal ini disebabkan semakin besar tekanan yang diberikan, semakin banyak air yang keluar dari matriks tahu sehingga kandungan protein lebih terkonsentrasi.

Tahu sutra terpilih memiliki kadar lemak yang paling tinggi jika dibandingkan dengan tahu sutra dan tahu reguler. Perbedaan kadar lemak ini diduga dipengaruhi oleh kadar lemak dari kedelai yang digunakan sebagai bahan baku dalam proses pembuatannya. Kedelai yang memiliki kadar lemak tinggi umumnya akan menghasilkan tahu dengan kadar lemak tinggi. Perbedaan jenis koagulan yang digunakan tidak memberikan pengaruh yang signifikan terhadap kandungan lemak tahu (Permana 2001). Tingginya kadar lemak dalam formula tahu terpilih diduga disebabkan karena kadar kedelai yang digunakan dalam penelitian ini lebih tinggi dibandingkan dengan kedelai yang digunakan dalam tahu reguler dan tahu sutra komersial.

Kadar karbohidrat dari tahu sutra terpilih berdasarkan basis kering memiliki nilai yang paling kecil jika dibandingkan dengan tahu reguler dan tahu sutra. Kadar karbohidrat pada tahu diduga dipengaruhi oleh varietas kedelai yang digunakan. Perbedaan lama waktu dan jumlah air perendaman juga diduga memengaruhi kadar karbohidrat tahu. Proses perendaman mampu mengurangi oligosakarida hingga 30\% (Purwaningsih 2007). Semakin lama waktu dan semakin 
banyak jumlah air perendaman yang digunakan maka akan semakin banyak oligosakarida ikut terbuang bersama air. Pada pembuatan tahu reguler, proses perendaman dilakukan selama 4 jam dengan volume air sebanyak 2 kali volume kedelai (Karsono 2010). Sedangkan pada pembuatan tahu sutra proses perendaman dilakukan selama 8 jam menggunakan air sebanyak 2 kali volume kedelai. Hal ini yang dimungkinkan menjadi penyebab rendahnya kadar karbohidrat total pada tahu sutra formula optimal.

\section{Karakteristik Tekstur Tahu Sutra Terpilih dengan Tahu Sutra Komersial}

Perbandingan pengukuran tekstur tahu sutra formula terpilih dan tahu sutra komersial dilakukan untuk mengetahui seberapa besar pengaruh penambahan karagenan terhadap mutu tekstur tahu sutra. Tahu sutra formula komersial yang dimaksud adalah tahu sutra yang tahapan pembuatannya menggunakan pendekatan pembuatan tahu sutra yang ada di pasaran dan hanya menggunakan kalsium sulfat saja sebagai koagulan. Berdasarkan hasil penelitian, penggunaan karagenan memberikan pengaruh yang signifikan terhadap nilai respon kekerasan, daya kohesif, elastisitas, dan daya kunyah tahu sutra. Hal ini sesuai dengan penelitian Li et al. (2015) yang menyebutkan bahwa aplikasi penggunaan karagenan pada pembuatan tahu dapat meningkatkan respon kekerasan secara signifikan. Hal ini disebabkan adanya interaksi segregatif antara karagenan dengan protein yang mampu meningkatkan gel strength. Peningkatan gel strength ini juga berpengaruh terhadap peningkatan elastisitas produk. Penambahan karagenan menyebabkan cross-linked antar rantai polimer yang terbentuk semakin banyak sehingga menghasilkan tahu yang padat dan kompak (Saha et al. 2010). Hal inilah yang menyebabkan nilai daya kohesif tahu sutra terpilih lebih tinggi dibandingkan dengan tahu sutra komersial. Daya kunyah merupakan hasil kali antara kekerasan, elastisitas dan daya kohesif sehingga nilai daya kunyah tahu sutra terpilih lebih tinggi jika dibandingkan dengan tahu sutra komersial.

\section{Sineresis Tahu Sutra Terpilih dan Tahu Sutra Komersial}

Pada penelitian ini dilakukan pengujian sineresis untuk membandingkan water holding capacity antara tahu sutra terpilih dan tahu sutra formula komersial. Pengukuran laju sineresis dilakukan setelah tahu sutra disimpan selama 24 jam pada suhu $10^{\circ} \mathrm{C}$. Berdasarkan hasil ANOVA penambahan karagenan dapat mengurangi laju sineresis tahu sutra secara signifikan $(\alpha=0,05)$, hal ini mengindikasikan bahwa penambahan karagenan mampu meningkatkan kemampuan water holding capacity dari tahu sutra terpilih. Hal ini sesuai dengan penelitian Karim et al. 1999 yang menyebutkan bahwa kemampuan karagenan dalam membentuk gel dapat memerangkap air di dalam jaringan lebih banyak sehingga mengurangi sineresis.

\section{KESIMPULAN}

Karagenan refined hasil ekstraksi memiliki karakteristik yang memenuhi standar FAO. Formula optimal yang direkomendasikan merupakan formula dengan kombinasi koagulan kalsium sulfat sebesar $0,45 \%$ dan karagenan $0,10 \%$ dengan nilai desirability sebesar $0,75 \%$. Nilai rendemen dari formula optimal tersebut adalah $85,36 \%$. Nilai kekerasan, daya kohesif, elastisitas, dan daya kunyah formula optimal secara berturut-turut sebesar 173,6 gf, 0,07; 0,54; dan 6,58 gf. Hasil pengujian sensori menunjukkan bahwa panelis secara keseluruhan lebih menyukai tahu sutra formula optimal dibandingkan dengan tahu sutra komersial secara signifikan. Dari hasil pengujian tekstur dapat disimpulkan bahwa penggunaan karagenan dapat meningkatkan respon kekerasan, daya kohesif, elastisitas, dan daya kunyah secara signifikan. Di sisi lain, penggunaan karagenan juga mampu menurunkan laju sineresis tahu sutra secara signifikan

\section{DAFTAR PUSTAKA}

Agustin TI. 2010. Aplikasi karaginan sebagai gelling agent kamaboko ikan kurisi. Prosiding Seminar Nasional Pengolahan Produk dan Bioteknologi Kelautan dan Perikanan II, 09 Agustus 2010. ID: BBRPPB-KKP. 167-174.

[AOAC] Association of Official Analytical Chemist. 2012. Official Methods of 
Analysis. Washington DC (USA) : AOAC International.

Basmal J, Syarifudin, Maaruf WF. 2003. Pengaruh konsentrasi larutan potasiium hidroksida terhadap mutu kappakaraginan yang diekstraksi dari Eucheuma cottonii. Jurnal Penelitian Perikanan Indonesia. 11 (8): 95-103.

Blazek V. 2008. Chemical and biochemical factors that influence the gelation of soybean protein and the yield of tofu [Tesis]. Sydney (AU): Faculty of Agriculture, Food and Natural Resources, The University of Sydney.

[BSN] Badan Standardisasi Nasional (ID). 1990. Tahu. Jakarta: Badan Standar Nasional

[BSN] Badan Standardisasi Nasional (ID). 2006. Petunjuk pengujian organoleptik dan atau sensori. SNI 01-2346-2006. Jakarta: Badan Standardisasi Nasional.

[BSN] Badan Standardisasi Nasional (ID). 2009. Rumput laut kering. SNI 2690.1:2009. Jakarta: Badan Standardisasi Nasional.

Campo LV, Kawano DF, da Silva DB, Carvalho JI. 2009. Carrageenans: Biological properties, chemical modifications and structural analysisi-A review. Journal Carbohydrate Polymers. 77: 167-180.

Chen YC, Chen CC, Chen ST Hsieh JF. 2016. Proteomic profiling of the coagulation of milk proteins induced by glucono- $\delta$ lactone. Food Hydrocolloid. 52: 137-143

Fahmi R. 2010. Mempelajari pengaruh jenis dan konsentrasi koagulan terhadap pola elektroforesis protein terkoagulasi serta korelasinya terhadap tekstur curd kedelai (Glycine max) yang dihasilkan [Skripsi]. Bogor (ID): Institut Pertanian Bogor.

[FAO] Food Agriculture Organization. 2007. Carrageenan. Prepared at the 68th JECFA and published in FAO JECFA Monographs 4: 1-6.

[FMC Corp] Food Marine Colloids Corp. 1977. Carrageenan. Marine Colloid Monograph Number One. US: Springfield New Jersey.

Glicksman M. 1983. Food Hydrocolloids Volume II. Florida: CRC Press.

Hayashi L, Edison J de Paula, Fungyi C. 2007a.
Gowth rate and carrageenan analyses in four strains of Kappaphycus alvarezii (Rhodophyta, Gigartinales) farmed in the subtropical waters of São Paulo State, Brazil. Journal of Applied Phycology. 19:393-399.

Hayashi L, Oliveira EC, Bleicher-Lhonneur G, Boulenguer P, Pereira RTL, von Seckendorff R, Shimoda VT, Leflamand A, Vallée P, Critchley AT. 2007b. Carrageenan analyses of Kappaphycus alvarezii (Rhodophyta, Solieriaceae) cultivated in different conditions in Ubatuba Bay, São Paulo, Brazil. Journal of Applied Phycology. 19: 505-511.

Ibrahim B, Uju, Soleh AM. 2020. Kinerja membran komposit kitosan-karagenan pada sistem microbial fuel cell dalam menghasilkan biolistrik dari limbah pemindangan ikan. Jurnal Pengolahan Hasil Perikanan Indonesia. 23(1): 137146.

Kao FJ, Su NW, Lee MH. 2003. Effect of calcium sulfate consentration in soy milk on the microstructure of firm tofu and protein constitution in tofu whey. Journal of Agricultural and Food Chemistry. 66: 259-165.

Karim AA, Sulebele GA, Azhar ME, Ping CY. 1999. Effect of carrageenan on rendemen and properties of tofu. Food Chemistry. 56 (2): 159-165.

Karsono Y. 2010. Pengaruh umur whey tahu dan suhu awal proses koagulasi terhadap pola elektroforesis protein terkoagulasi dan mutu tekstur curd kedelai [Skripsi]. Bogor (ID): Institut Pertanian Bogor.

Li M, Fusheng C, Bao Y, Shaojuan L, Hongshun Y, Kunlun L, Guanhao B, Caili F, Yun D. 2015. Preparation of organic tofu using organic compatible magnesium chloride incorporated eith polysaccharide coagulants. Journal of Food Chemistry 167: 168-174.

Mullin WJ, Fregeau-Reid JA, Butler M, Poysa V, Woodrow L. 2001. An interlaboratory test of a procedure to assess soybean quality for soymilk and tofu production. Food Research International. 34: 669-677.

Munoz J, Freile-Pelegin Y, Robledo D. 2004. Mariculture of Kappaphycus alvarezii 
(Rhodophyta, Solieriaceae) colour strains in tropical waters of Yucatan, Mexico. Aquaculture. 239: 161-177.

Murdia LK, Wadhwani R. 2010. Effect of processing parameters on texture and yield of tofu. Journal of Food and Agro Industry. 3 (02): 232-241.

Nishinari K, Fang Y, Guo S, Phillips GO. 2014. Soy proteins: a review on composition, aggregation and emulsification. Journal Food Hydrocolloids 39: 301-318.

Obatolu VA. 2007. Effect of different coagulants on rendemen and quality of tofu from soymilk. Journal European Food Research and Technology. 226:467-427.

Padil, Yelmida A, Candra M. 2011. Optimasi hidrolisis tandan kosong sawit menggunakan rancangan percobaan respone surface methodology. Journal Sains dan Teknologi. 10(1): 42-46.

Permana I. 2001. Pengaruh varietas kedelai (Glycine max Mer.) dan jenis koagulan pada rendemen dan kualitas tahu [Skripsi]. Bogor (ID): Institut Pertanian Bogor.

Poysa V, Woodrow L. 2002. Stability of soybean seed composition and its effect on tofu yield and quality. Food Research International. 35: 337-345.

Prabhakaran MP, Perera CO, Valiyaveettiil S. 2006. Effect of different coagulants on the isoflavone levels and physical properties of prepared from tofu. Food Chemistry. 99: 492-499.

Qotimah K, Dewi EN, Purnamayati L. 2020. Karakteristik mutu edible film karagenan dengan penambahan minyak atsiri bawang putih (Allium sativum). Jurnal Pengolahan Hasil Perikanan Indonesia. 23(1): 1-9

Sanusi A. 2006. Formulasi sagu instan sebagai makanan tinggi kalori [Skripsi]. Bogor (ID): Institut Pertanian Bogor.
Saha D, Auvendu B. 2010. Hydrocolloids as thickening and gelling agents in food: a critical review. Journal Food Science and Technology. 47 (6): 587-597.

Septiana HN. 2011. Formulasi serbuk tahu sutra instan menggunakan metode respon permukanan (response surface methodology) [Skripsi]. Bogor(ID): Institut Pertanian Bogor.

Shih MC, Hou HJ, Chang KC. 1997. Process Optimization for Soft Tofu. Journal of Food Science. 62(4): 833-837

Siregar RF, Santoso J, Uju. 2016. Karakteristik fisiko kimia kappa karaginan hasil degradasi menggunakan hidrogen peroksida. Jurnal Pengolahan Hasil Perikanan Indonesia. 19(3): 256-266.

Sun N, William M, M. Breene. 1991. Calcium sulfate concentration influence on yield and quality of tofu from five siybean varieties. Journal of Food Science. 56 (6): 1604-1607.

Suptijah P, Suseno S, Kurniawati N. 2012. Aplikasi karagenan sebagai cangkang kapsul keras alternatif pengganti kapsul gelatin. Jurnal Pengolahan Hasil Perikanan Indonesia. 15(3): 223-231.

Yuan C, Meng-I K. 2011. Effect of gammapolyglutamate on the rheological properties and microstructure of tofu. Food Hydrocolloids. 25: 1034-1040.

Yuwono SS, Susanto T. 2006. Pengaruh perbandingan kedelai:air pada proses ekstraksi terhadap ekstraktabilitas padatan, protein, dan kalsium kedelai serta rasio fraksi protein $7 \mathrm{~S} / 11 \mathrm{~S}$. Jurnal Teknologi Pertanian. 7 (2): 71-77.

Winarno FG. 1996. Teknologi Pengolahan Rumput Laut. Jakarta (ID): Gramedia Pustaka Utama. 